\title{
Rapportage over prestaties in de Europese Unie: Baby- lonische spraakverwarring?
}

\section{Arjan Brouwer}

SAMENVATTING In dit artikel wordt verslag gedaan van een onderzoek naar de presentatie van de winst-en-verliesrekening in de jaarrekening 2005, en het gebruik van alternatieve winstbegrippen in jaarverslagen ${ }^{1}$ over zowel 2004 als 2005 door ondernemingen in de Europese Unie (EU). Uit het onderzoek blijkt dat sprake is van grote diversiteit binnen de EU in zowel de presentatie van de winst-en-verliesrekening, als het gebruik van alternatieve winstbegrippen elders in het jaarverslag. Dit roept de vraag op of de invoering van IFRS in de EU heeft geleid tot de gewenste hoge mate van vergelijkbaarheid. Waar het de presentatie van informatie betreft, lijkt hier nog veel ruimte voor verbetering te bestaan.

\section{Inleiding}

Voor veel ondernemingen in de EU was 2005 het eerste jaar dat zij hun jaarrekening op basis van International Financial Reporting Standards (IFRS) opstelden. Een belangrijke doelstelling van de invoering van IFRS, zoals gecommuniceerd door de EU, is het bereiken van een hoge mate van transparantie en vergelijkbaarheid van de financiële informatie van alle beursgenoteerde ondernemingen in de EU. Hierdoor kan een doeltreffende en soepel werkende geïntegreerde kapitaalmarkt opgebouwd worden.

Het verschaffen van informatie over de prestaties ('performance') van de onderneming is een belangrijke doelstelling van de jaarrekening (IASB, Frame-

Drs. A.J. Brouwer RA is senior manager bij PricewaterhouseCoopers en als docent externe verslaggeving verbonden aan de Universiteit van Amsterdam. Momenteel doet hij een promotieonderzoek op het gebied van het gebruik van winstbegrippen in de jaarrekening. Dit artikel is geschreven op persoonlijke titel. work, paragraaf 12). Op de vraag hoe de prestaties van een onderneming gemeten en weergegeven moeten worden, bestaat echter geen eenduidig antwoord. Dekker (2005) merkt op dat een duidelijke definitie van 'performance' ontbreekt, en wijst op problemen die dit in de praktijk oplevert. Performance is een breed begrip en zal door verschillende personen verschillend worden geïnterpreteerd. Waar de één zich richt op het nettoresultaat, kijkt een ander naar de operationele kasstroom en een derde naar nietfinanciële prestatiemaatstaven.

Volgens het Framework (paragraaf 69) wordt de winst van een onderneming veelvuldig gebruikt als een maatstaf om de resultaten te beoordelen of als de basis voor andere maatstaven, zoals het rendement van een belegging of de winst per aandeel. Aangegeven wordt dan ook dat informatie over resultaten in de eerste plaats in een winst-en-verliesrekening wordt verschaft. Vlotman (2005a) geeft aan dat de economische winst het ideale winstbegrip zou zijn voor het extern weergeven van de prestaties van een onderneming. Vlotman geeft aan dat een onderneming haar waarde ontleent aan het vermogen om in de toekomst positieve kasstromen op te wekken en dat het resultaat van de onderneming derhalve dient te worden afgeleid uit een vergelijking van de toekomstige kasstromen. Alle andere winstbegrippen acht hij second best. Dit economisch winstbegrip wordt in de praktijk echter zelden gebruikt voor externe verslaggeving. In de praktijk hanteren ondernemingen naast de nettowinst verschillende winstbegrippen om inzicht te geven in hun prestaties. Meestal zijn dat winstbegrippen die bepaalde eenmalige kosten buiten beschouwing laten, om inzicht te geven in het naar verwachting terugkerende resultaat. Daarnaast worden regelmatig begrippen gehanteerd die bepaalde kostensoorten buiten beschouwing laten, zoals afschrijvingskosten. Dit met de gedachte om inzicht te geven in het kasstroomgenererend vermogen van de onderneming. 
Verschillende partijen hebben de zorg geuit dat de invoering van IFRS níet zal leiden tot de door de EU beoogde vergelijkbaarheid van jaarrekeningen, ondanks de toepassing van eenzelfde set standaarden. De vergelijkbaarheid zou zelfs kunnen afnemen, doordat er geen voorgeschreven presentatiewijze is van, onder andere, de winst-en-verliesrekening (zie onder andere CESR, 2005b en EFRAG, 2006). Bovendien zou dit volgens hen kunnen leiden tot een toename van het gebruik van alternatieve winstbegrippen ('non-GAAP measures'). Marseille en Vergoossen (2005) stellen bijvoorbeeld dat het gebrek aan modellen voor de winst-en-verliesrekening onder IFRS het gebruik van alternatieve financiële prestatieindicatoren in de hand werkt.

In dit artikel wordt verslag gedaan van een onderzoek naar de presentatie van de winst-en-verliesrekening in de jaarrekening 2005, en het gebruik van alternatieve winstbegrippen in jaarverslagen over zowel 2004 als 2005 van ondernemingen uit de EU. Om inzicht te krijgen in de wijze waarop ondernemingen hun resultaten hebben gerapporteerd in de eerste IFRS-jaarrekening, heb ik allereerst de presentatie van de winst-en-verliesrekening van 250 ondernemingen uit 8 landen onderzocht. In paragraaf 2 wordt ingegaan op de resultaten van dit onderzoek. De resultaten uit dit onderzoek, alsmede de wetenschap dat het gebruik van winstbegrippen zich verder uitstrekt dan slechts de winst-en-verliesrekening zelf, zijn anleiding geweest om voor een aantal landen het onderzoek uit te breiden en te richten op het gebruik van winstbegrippen in het gehele jaarverslag. Hiervoor zijn de grootste kapitaalmarkten van de EU, het Verenigd Koninkrijk, Duitsland en Frankrijk, alsmede Nederland geselecteerd. In paragraaf 3 worden de resultaten van dit deel van het onderzoek besproken. In beide paragrafen wordt allereerst de belangrijkste regelgeving besproken, waarna de resultaten van het onderzoek worden gepresenteerd. In paragraaf 4 worden de oorzaken en consequenties van de bevindingen besproken.

\section{2}

\section{Presentatie van de winst-en-verliesrekening}

\subsection{Presentatie van de winst-en-verliesrekening- regelgeving}

Tot en met 2004 stelde het merendeel van de ondernemingen in de EU een jaarrekening op volgens de lokale wet- en regelgeving. In Nederland is dat BW 2 Titel 9. De lokale wetgeving in landen binnen de EU is gebaseerd op de Vierde en Zevende EG-richtlijn, welke gedetailleerde voorschriften bevat voor de inrichting van de winst-en-verliesrekening. In Nederland is dit uitgewerkt in het Besluit modellen jaarrekening (BMJ). Van de posten en indeling die in het BMJ zijn voorgeschreven, kan slechts beperkt worden afgeweken. In ieder geval is het niet toegestaan de volgorde van posten in de winst-en-verliesrekening te wijzigen.

Backhuijs en Mertens (2000) constateerden echter op basis van onderzoek naar jaarverslagen over het jaar 1999 van 37 Nederlandse beursfondsen, dat meerdere ondernemingen winstbegrippen hanteerden in de winst-en-verliesrekening die niet verenigbaar zijn met het BMJ. Mede naar aanleiding hiervan heeft de Raad voor de Jaarverslaggeving (RJ) in 2001 in Richtlijn 270 'De winst-en-verliesrekening' expliciet aangegeven dat het gebruik van EBITA (Earnings Before Interest, Taxes and Amortization) en EBITDA (Eranings Before Interest, Taxes, Depreciation and Amortization) in de winst-en-verliesrekening onverenigbaar is met het BMJ en dat het gebruik hiervan alleen mogelijk is in de toelichting. Dit heeft in eerste instantie echter niet geleid tot een afname van het gebruik van alternatieve winstbegrippen als EBITA en EBITDA. Tussen 1999 en 2002 is er zelfs een sterke groei waar te nemen in het gebruik van deze begrippen: in 1999 kwamen deze begrippen nog slechts in circa $17 \%$ van de jaarverslagen van de Nederlandse beursfondsen voor, terwijl ze in 2002 bij $46 \%$ van de beursfondsen voorkwamen (Brouwer, 2007). Hooghiemstra en Van der Tas (2003) constateren het gebruik van EBITA en/of EBITDA als tussentelling in de winst-en-verliesrekening in 13 van de 33 (33\%) door hun onderzochte jaarrekeningen over het jaar 2002.

In januari 2004 heeft het Koninklijk Nederlands Instituut voor Registeraccountants (Het Financieele Dagblad, 2004a, 2004b) geageerd tegen het gebruik van deze begrippen in de winst-en-verliesrekening en in februari 2004 heeft ook de Autoriteit Financiële Markten gewaarschuwd tegen het gebruik hiervan. Waarschijnlijkals gevolghiervan vinden Hooghiemstra en Van der Tas (2004) in hun onderzoek van 37 jaarrekeningen over het jaar 2003 nog slechts drie beursfondsen die EBITA hanteren en komen ze het begrip EBITDA niet meer tegen in de winst-en-verliesrekening. Dit betekent overigens niet dat het gebruik in andere delen van het jaarverslag even sterk afneemt. Brouwer (2007) signaleert een lichte daling in 2003, maar daarna weer een lichte stijging. In 2005 gebruikt iets meer dan $50 \%$ van de Nederlandse beursfondsen deze begrippen in het jaarverslag (zie paragraaf 3.2). 
Voor ondernemingen die IFRS toepassen, zijn de lokale wettelijke vereisten voor de presentatie van de winst-en-verliesrekening niet meer van toepassing. Zij dienen de winst-en-verliesrekening in te richten in overeenstemming met IAS 1 ('Presentation of Financial Statements'). IAS 1 schrijft opname van een beperkt aantal regels in de winst-en-verliesrekening voor, maar geen detailindeling. Daarnaast dienen op grond van IAS 1 additionele posten, kopjes en subtotalen in de winst-en-verliesrekening te worden gepresenteerd, indien een dergelijke presentatie relevant is voor een goed inzicht in de financiële prestaties van de onderneming. Hierbij is expliciet verboden dat baten of lasten als buitengewone posten worden gepresenteerd. Onder IFRS bestaat daarom een vrij grote mate van vrijheid bij de presentatie van de resultaten van de onderneming. Enerzijds geeft dit het management de kans om aan de gebruikers begrijpelijke en relevante informatie te geven die aansluit op de specifieke ondernemingsactiviteiten. Anderzijds kan dit er ook toe leiden dat het management opportunistische keuzes maakt door prestatiemaatstaven op te nemen die een ander, gunstiger, beeld geven dan de gerapporteerde nettowinst. Daarnaast kan de toegenomen vrijheid ertoe leiden dat de vergelijkbaarheid van jaarrekeningen en gepresenteerde resultaten afneemt.

\subsection{Presentatie van de winst-en-verliesrekening- praktijkonderzoek}

\subsubsection{Selectie}

Heeft de relatief grote mate van vrijheid bij het presenteren van de winst-en-verliesrekening in de praktijk nu ook daadwerkelijk geleid tot een grote mate van diversiteit? Om hier antwoord op te kunnen krijgen, zijn de IFRS-jaarrekeningen onderzocht van

\begin{tabular}{l}
\hline Tabel 1: Selectie IFRS-jaarrekeningen \\
\begin{tabular}{|l|r|r|}
\hline Land & Aantal & Percentage \\
\hline Verenigd Koninkrijk & 71 & $28 \%$ \\
\hline Duitsland & 42 & $17 \%$ \\
\hline Frankrijk & 40 & $16 \%$ \\
\hline Nederland & 25 & $10 \%$ \\
\hline Denemarken & 25 & $10 \%$ \\
\hline België & 19 & $8 \%$ \\
\hline Italië & 15 & $6 \%$ \\
\hline Spanje & 13 & $5 \%$ \\
\hline Totaal & $\mathbf{2 5 0}$ & $\mathbf{1 0 0 \%}$ \\
\hline
\end{tabular}
\end{tabular}

250 willekeurig $^{2}$ geselecteerde beursfondsen uit acht landen binnen de EU.

\subsubsection{Diversiteit in presentatie}

De resultaten laten een grote diversiteit zien in de presentatie van de winst-en-verliesrekening. Dit kan worden geillustreerd aan de hand van het aantal regels dat de winst-en-verliesrekening van de geselecteerde ondernemingen bevat. Dit aantal varieert van 8 tot 48 . Het aantal winstbegrippen (tussentellingen die een saldo van opbrengsten en bepaalde kosten weergeven) varieert tussen twee en acht. Het is derhalve duidelijk dat er geen overeenstemming bestaat over hoe gedetailleerd de informatie moet zijn in de winst-en-verliesrekening. Wel gebruikt een grote meerderheid (59\%) van de ondernemingen tussen de 15 en 20 regels voor deze informatie. Slechts $2 \%$ neemt minder dan 10 regels op in de winst-enverliesrekening, en $14 \%$ meer dan 20 regels. Op basis van de regelgeving is er geen sprake van 'goed' of 'fout'. Men zou kunnen stellen dat meer gedetailleerde informatie in de winst-en-verliesrekening altijd goed is, maar wellicht bestaat er ook een grens aan de hoeveelheid informatie die de lezer van de jaarrekening tot zich kan nemen.

Vooral de ondernemingen uit het Verenigd Koninkrijk hanteren naast de presentatie van posten en subtotalen op de regels van de winst-en-verliesrekening een specifieke presentatievorm. Gebaseerd op de vereisten van FRS 3 'Reporting Financial Performance', gebruikt een groot aantal ondernemingen uit het Verenigd Koninkrijk aanvullende kolommen of subanalyses om aanvullende specificaties te presenteren van de resultaten. Deze ondernemingen gebruiken deze presentatievorm ook onder IFRS. Bijna 25\% van de ondernemingen uit het Verenigd Koninkrijk in de selectie presenteert afzonderlijke kolommen in de winst-en-verliesrekening om bepaalde specifieke posten te benadrukken. Ongeveer $20 \%$ van de ondernemingen gebruikt afzonderlijke subanalyses in de winst-en-verliesrekening. In de andere landen binnen de populatie komt deze manier van presenteren veel minder voor; in veel landen komt het zelfs in het geheel niet voor.

De meeste ondernemingen gebruiken de afzonderlijke kolommen om de bijzondere posten (66\%) en de gestaakte activiteiten (26\%) afzonderlijk weer te geven. Subanalyses worden vooral gebruikt om waardevermindering en afschrijvingen (36\%) of bijzondere posten $(25 \%$, waarvan 16 procentpunt verband houdt met reorganisatiekosten) weer te geven. 
Alle onderzochte ondernemingen rapporteren aanvullende prestatiecriteria in vergelijking met de minimumvereisten van IAS 1 . Van de onderzochte ondernemingen rapporteert in totaal $43 \%$ vier winstbegrippen in de winst-en-verliesrekening, gevolgd door $27 \%$ die er drie en $20 \%$ die er vijf rapporteren.

Tabel 2: Aantal winstbegrippen in de winst-en-verliesrekening
\begin{tabular}{|l|r|r|}
\hline Aantal winstbegrippen & Aantal ondernemingen & Percentage \\
\hline 2 winstbegrippen & 3 & $1 \%$ \\
\hline 3 & 68 & $27 \%$ \\
\hline 4 & 107 & $43 \%$ \\
\hline 5 & 49 & $20 \%$ \\
\hline 6 & 20 & $8 \%$ \\
\hline 7 & 2 & $1 \%$ \\
\hline 8 & 1 & $0 \%$ \\
\hline Totaal & $\mathbf{2 5 0}$ & $100 \%$ \\
\hline
\end{tabular}

Bijna $85 \%$ van de ondernemingen rapporteert het operationeel resultaat en in totaal $96 \%$ van de ondernemingen rapporteert óf het operationele resultaat óf EBIT (resultaat voor interest en belastingen). Hiermee voldoen de ondernemingen aan een behoefte die in de praktijk lijkt te bestaan bij de gebruikers van de jaarrekening. In interviews van de Financial Accounting Standards Board (FASB) met analisten en andere gebruikers, geven veel analisten bijvoorbeeld aan dat operationeel resultaat en EBIT bij de belangrijkste maatstaven horen die door hen gebruikt worden om de prestatie van de onderneming te beoordelen (FASB, 2002). De FASB berichtte dat nagenoeg alle geïnterviewden een voorkeur hebben voor het classificeren van posten als operationeel of niet-operationeel. Ze gaven echter ook aan dat er geen overeenstemming of duidelijkheid is over de definitie of onderliggende gedachte van het begrip 'operationeel'. Dit wordt bevestigd in dit onderzoek: in de praktijk worden verschillende definities gehanteerd voor het operationele resultaat. Bij veel ondernemingen betreft het hier het resultaat voor interest en belastingen. In de meeste gevallen wordt ook het resultaat van (minderheids)deelnemingen buiten beschouwing gelaten. Andere ondernemingen laten daarnaast bepaalde bijzondere posten buiten beschouwing.

Winstbegrippen die de afgelopen jaren regelmatig onderwerp van discussie zijn geweest, zijn de winstbegrippen die waardeverminderingen en/of afschrijvingen buiten beschouwinglaten en degenormaliseerde winstbegrippen (zie onder andere IOSCO Technical Committee, 2002 en FD, 2004a).

\subsubsection{EBITDA en vergelijkbare begrippen in de winst-en-} verliesrekening

Ongeveer $10 \%$ van de geselecteerde ondernemingen rapporteert EBITDA of EBITA als een subtotaal in de winst-en-verliesrekening, waarbij er duidelijke verschillen te zien zijn tussen de landen. In Denemarken en Italië rapporteert ongeveer een derde van de geselecteerde ondernemingen een tussentelling voor EBITDA of EBITA, terwijl dit in het Verenigd Koninkrijk en in Nederland ongebruikelijk is. Wel rapporteert een aantal (ongeveer 7\%) ondernemingen uit het Verenigd Koninkrijk dergelijke begrippen in afzonderlijke subanalyses die in of bij de winst-en-verliesrekening worden gepresenteerd. Voor Nederland zijn 25 ondernemingen meegenomen in het onderzoek. Geen van deze ondernemingen hanteerde EBITDA of EBITA in de winst-en-verliesrekening ${ }^{3}$. Dit lage aantal heeft mogelijk te maken met het eerder genoemde expliciete verbod dat is opgenomen in de Richtlijnen voor de jaarverslaggeving, welke tot en met 2004 op deze ondernemingen van toepassing waren.

Tabel 3: Percentage ondernemingen met EBITDA of EBITA in
de winst-en-verliesrekening
\begin{tabular}{|l|r|}
\hline Land & Percentage \\
\hline Italië & $33 \%$ \\
\hline Denemarken & $32 \%$ \\
\hline Spanje & $15 \%$ \\
\hline België & $11 \%$ \\
\hline Duitsland & $10 \%$ \\
\hline Frankrijk & $8 \%$ \\
\hline Verenigd Koninkrijk & $1 \%$ \\
\hline Nederland & $0 \%$ \\
\hline
\end{tabular}

\subsubsection{Genormaliseerde winstbegrippen in de winst-en- verliesrekening}

Het is onder IFRS niet toegestaan om posten als buitengewone baten en lasten weer te geven. Toch hebben veel ondernemingen besloten om naar verwachting niet-terugkerende posten op een bepaalde manier afzonderlijk weer te geven in de winst-en-verliesrekening. $\mathrm{Ze}$ hebben diverse manieren en rubrieken gevonden om dat te doen. De volgende winstbegrippen worden onder andere gehanteerd om het genormaliseerde resultaat weer te geven: 
- Result before non-recurring items (resultaat vóór niet-terugkerende posten);

- Result before exceptional items (resultaat vóór bijzondere posten);

- Result before significant items (resultaat vóór significante posten);

- Result before special items (resultaat vóór speciale posten);

- Result before specific items (resultaat vóór specifieke posten);

- Normalized result (genormaliseerd resultaat);

- Underlying result (onderliggende resultaat); en

- Current operating result (courant operationeel resultaat).

Ongeveer 25\% van de onderzochte ondernemingen rapporteert een resultaat vóór bepaalde niet-terugkerende posten als een subtotaal in de winst-en-verliesrekening, waarvan $14 \%$ als tussentelling in de regels van de winst-en-verliesrekening en $6 \%$ via het gebruik van afzonderlijke kolommen. Zie ook tabel 4.

Zie ook paragraaf 3.2.3 voor meer details omtrent de rapportering van genormaliseerde resultaten.

\subsubsection{Nationale achtergronden}

De uitkomsten duiden op een belangrijke invloed van nationale achtergronden op de presentatie van de winst-en-verliesrekening. Het hanteren van afzonderlijke kolommen en subanalyses in het Verenigd Koninkrijk bijvoorbeeld, is duidelijk beïnvloed door FRS 3. Ook het Financial Reporting Review Panel (FRRP) in het Verenigd Koninkrijk geeft in haar rapport naar aanleiding van de review van de jaarrekeningen van beursfondsen in het Verenigd Koninkrijk aan dat veel ondernemingen een indeling voor de winst-en-verliesrekening gebruikten die dezelfde is als de winst-en-verliesrekening die vroeger onder UK GAAP gebruikt werd (FRRP, 2006).
Het grote aantal Franse ondernemingen dat resultaten voor bijzondere posten rapporteert, is ongetwijfeld beïnvloed door de aanbevelingen van het 'Conseil national de la comptabilité' (CNC, 2004) om afzonderlijk bijzondere posten te rapporteren en om een subtotaal 'Resultat operationnel courant' op te nemen. Dit begrip is overigens door de meeste ondernemingen vertaald als 'Current operating income', wat op het eerste gezicht een net iets andere lading lijkt te hebben. Het Engelse begrip current verwijst eerder naar de toepassing van een actueel waardebegrip dan naar een resultaat exclusief bijzondere posten.

\section{Rapportage van alternatieve prestatiecriteria}

\subsection{Rapportage van alternatieve prestatiecriteria- regelgeving}

Een belangrijk deel van de rapportage over de resultaten van de onderneming vindt niet plaats in de jaarrekening, maar in het directieverslag. Hierin geeft het management onder andere een analyse van de resultaten die in het afgelopen jaar behaald zijn. Het bestuur heeft de mogelijkheid om uit te leggen hoe de resultaten zijn opgebouwd en kan in detail ingaan op de ontwikkelingen die van invloed waren op de resultaten. Veel ondernemingen gebruiken hierbij alternatieve prestatiecriteria, zowel financiële als niet-financiële. Deze alternatieve prestatiecriteria lijken steeds belangrijker te worden (zie ook Brouwer, 2007).

IFRS bevat nog geen standaard met betrekking tot dit element van de financiële verslaggeving. Op dit onderdeel is over het algemeen lokale regelgeving van toepassing, welke doorgaans beperkt is. Wel zijn eind jaren negentig de discussies omtrent het gebruik van alternatieve winstbegrippen in de financiële verslaggeving opgelaaid. Dit is begonnen met een groot

Tabel 4: Resultaat voor niet-terugkerende posten in de winst-en-verliesrekening

\begin{tabular}{|c|c|c|c|c|c|}
\hline Land & Subtotaal in de regels & Subtotaal in de kolommen & Aparte subanalyses & Combinatie & Totaal \\
\hline Frankrijk & $55 \%$ & $0 \%$ & $0 \%$ & $0 \%$ & $55 \%$ \\
\hline Verenigd Koninkrijk & $4 \%$ & $18 \%$ & $14 \%$ & $1 \%$ & $38 \%$ \\
\hline Italië & $27 \%$ & $0 \%$ & $0 \%$ & $0 \%$ & $27 \%$ \\
\hline Denemarken & $12 \%$ & $0 \%$ & $0 \%$ & $0 \%$ & $12 \%$ \\
\hline Nederland & $0 \%$ & $4 \%$ & $8 \%$ & $0 \%$ & $12 \%$ \\
\hline Spanje & $8 \%$ & $0 \%$ & $0 \%$ & $0 \%$ & $8 \%$ \\
\hline Duitsland & $7 \%$ & $0 \%$ & $0 \%$ & $0 \%$ & $7 \%$ \\
\hline België & $0 \%$ & $5 \%$ & $0 \%$ & $0 \%$ & $5 \%$ \\
\hline
\end{tabular}


aantal 'comment letters' van de Amerikaanse Securities and Exchange Commission (SEC), over het gebruik ervan (zie onder andere SEC, 2001). Na een aantal publiekelijk geuite waarschuwingen is de SEC in 2002 voor het eerst een procedure gestart tegen een onderneming vanwege vermeend misleidend gebruik van zogenaamde pro forma winstbegrippen (SEC, 2002). In 2003 heeft de SEC regelgeving uitgebracht om een eind te maken aan het ongeremde gebruik van alternatieve winstbegrippen (SEC, 2003).

In een bredere internationale context heeft de G4+1 (een werkgroep van een aantal internationale regelgevers en, destijds, het IASC) eind jaren negentig twee rapporten uitgebracht: 'Reporting Financial Performance: current developments and future directions' en 'Reporting Financial Performance: proposals for change' (G4+1, 1999). Deze rapporten zijn mede aanleiding geweest voor de IASB om het 'performance reporting project' te starten, dat in 2004 tot een gezamenlijk project van de IASB en FASB heeft geleid, dat inmiddels is omgedoopt tot 'Financial statement presentation'. Belangrijke concrete resultaten heeft dit project tot op heden echter nog niet opgeleverd.

Totdat dit project en het 'Management Commentary' project (zie IASB 2005) zijn afgerond, hebben de Europese ondernemingen nog een vrij grote mate van vrijheid bij het gebruik van alternatieve winstbegrippen. In oktober 2005 heeft de Europese organisatie van beurstoezichthouders CESR wel een aanbeveling uitgebracht voor de Europese beursfondsen over het gebruik van alternatieve winstbegrippen. CESR doet de volgende aanbevelingen:

- De kwalitatieve kenmerken voor financiële informatie (begrijpelijkheid, relevantie, betrouwbaarheid en vergelijkbaarheid) dienen in acht genomen te worden bij het gebruik van alternatieve winstbegrippen.

- Alternatieve winstbegrippen dienen duidelijk gedefinieerd te worden.

- Alternatieve winstbegrippen dienen zoveel mogelijk samen met gedefinieerde winstbegrippen te worden gepresenteerd en het verschil met (aansluiting naar) de gedefinieerde winstbegrippen dient duidelijk uiteengezet te worden.

- Vergelijkende cijfers dienen te worden opgenomen.

- Alternatieve winstbegrippen dienen consistent in de tijd te worden gebruikt.

- De onderneming dient uit te leggen waarom alternatieve winstbegrippen worden gepresenteerd en hoe ze intern worden gebruikt. En:

- De onderneming dient toe te lichten of de alternatieve winstbegrippen afzonderlijk zijn beoordeeld door een accountant en, als dat het geval is, wat de aard en het oordeel hiervan was.

Een volledig verbod op het gebruik van alternatieve winstbegrippen en prestatie-indicatoren lijkt geen oplossing te zijn. Analisten hebben behoefte aan meer informatie die hun een beter inzicht geeft in de performance van de onderneming dan de nettowinst alleen. Uit de rapportage van de FASB over de door haar gehouden interviews onder 56 analisten (FASB, 2002), komt bijvoorbeeld naar voren dat zij zich niet zozeer richten op de nettowinst, maar dit eerder zien als een startpunt voor de berekening van andere winstbegrippen. De Jong en Roelofsen (2005) rapporteren dat analisten in conference calls naar aanleiding van de IFRS-conversie van beursgenoteerde ondernemingen regelmatig hebben gevraagd naar de invloed op pro forma cijfers en ratio's.

\subsection{Rapportage van alternatieve prestatiecriteria-praktijkonderzoek}

\subsubsection{Selectie}

Een groot deel van de informatieverschaffing over de resultaten van de onderneming vindt niet alleen plaats via de winst-en-verliesrekening, maar ook door middel van de rapportage over resultaten en winstbegrippen in het directieverslag en de overige opgenomen informatie. Om die reden heb ik ook de rapportage van winstbegrippen in deze delen van het jaarverslag onderzocht. Om meer inzicht te krijgen in de verschillen tussen landen is besloten om het vervolg van het onderzoek te richten op een beperkter aantal landen, waarvoor vervolgens een grotere populatie ondernemingen is onderzocht. Het tweede deel van het onderzoek is uitgevoerd onder een grote groep ondernemingen uit Nederland en uit de drie grootste Europese kapitaalmarkten: het Verenigd Koninkrijk, Frankrijk en Duitsland.

\subsubsection{EBITDA en vergelijkbare begrippen}

De jaarverslagen zijn onderzocht op het gebruik van bepaalde alternatieve prestatiecriteria. De eerste groep

Tabel 5: Aantal onderzochte ondernemingen per land
\begin{tabular}{|l|r|r|}
\hline Land & Aantal & Percentage \\
\hline Verenigd Koninkrijk & 644 & $45 \%$ \\
\hline Duitsland & 463 & $33 \%$ \\
\hline Frankrijk & 167 & $12 \%$ \\
\hline Nederland & 138 & $10 \%$ \\
\hline Totaal & $\mathbf{1 4 1 2}$ & $\mathbf{1 0 0 \%}$ \\
\hline
\end{tabular}


van prestatiecriteria waar het onderzoek op is gericht, zijn de criteria die waardeverminderingen en/of afschrijvingen buiten beschouwing laten, zoals Earnings Before Interest, Taxes and Amortization (EBITA), Earnings Before Interest, Taxes, Depreciation and Amortization (EBITDA), Earnings Before Interest, Taxes, Amortization and Exceptional items (EBITAE) en Earnings Before Interest, Taxes, Depreciation, Amortization and Exceptional items (EBITDAE). Hieruit blijkt dat in 2005 in $59 \%$ van de Duitse, 50\% van de Franse, 32\% van de uit het Verenigd Koninkrijk afkomstige en 53\% van de Nederlandse jaarverslagen zulke criteria voorkomen (gewogen gemiddelde: 45\%; 2004: 44\%). Vooral in Frankrijk is een stijging ten opzichte van 2004 zichtbaar: van $46 \%$ in 2004, naar 50\% in 2005. In de andere landen is het gebruik stabiel.

Tabel 6: Percentage van ondernemingen dat EBITDA en vergelijkbare begrippen rapporteert in de jaarverslagen

\begin{tabular}{|l|c|c|}
\hline Land & $\mathbf{2 0 0 5}$ & $\mathbf{2 0 0 4}$ \\
\hline Duitsland & $59 \%$ & $59 \%$ \\
\hline Nederland & $53 \%$ & $53 \%$ \\
\hline Frankrijk & $50 \%$ & $46 \%$ \\
\hline Verenigd Koninkrijk & $32 \%$ & $31 \%$ \\
\hline Gewogen gemiddelde & $\mathbf{4 5 \%}$ & $\mathbf{4 4 \%}$ \\
\hline
\end{tabular}

De resultaten geven duidelijk aan dat er regionale verschillen zijn in de verslaggeving van alternatieve prestatiecriteria.

\subsubsection{Genormaliseerde winstbegrippen}

Alhoewel IFRS het gebruik van buitengewone basten en lasten verbiedt, geven gebruikers aan dat ze behoefte hebben aan informatie over de mate waarin het resultaat voortkomt uit de reguliere bedrijfsactiviteiten en naar verwachting terugkerend is. Kamp (2002) geeft aan dat de kwaliteit van de winst als hoog wordt angeduid als deze (1) afkomstig is uit de primaire activiteiten van de onderneming, (2) goed voorspelbaar is, en (3) in liquide vorm is gerealiseerd. In de rapportage van de FASB-interviews (FASB, 2002) wordt een suggestie gegeven ter verbetering van de presentatie van informatie in de jaarrekening. Aangegeven wordt dat indien een duidelijk onderscheid wordt gemaakt tussen elementen die meer of minder (1) variabel, (2) onderhevig aan managementbeïnvloeding, (3) terugkerend en (4) onderhevig aan 'zachtere' waarderingen of onvoorspelbare marktwaarden zijn, dit het inzicht in de prestaties van de onderneming zal verbeteren.
Het eerst inperken en later zelfs verbieden van het gebruik van buitengewone posten binnen IFRS lijkt op een vorm van antimisbruikregelgeving. Wellicht is dit een reactie van regelgevers geweest op het vermoeden dat ondernemingen niet consistent omgingen met het aanmerken van positieve en negatieve posten als buitengewoon. Vander Bauwhede (2003) geeft een overzicht van literatuur over resultaatsturing waarin indicaties worden gevonden dat ondernemingen het resultaat trachten te egaliseren. Vander Bauwhede gaat hier met name in op het gebruik van 'accruals' om het resultaat te egaliseren, maar ook egalisatie van het resultaat uit gewone bedrijfsuitoefening is mogelijk door trendverstorende resultaten als buitengewoon an te merken. Die mogelijkheid bespreekt Vander Bauwhede niet. Zoals hierna zichtbaar zal worden, lijkt het verbod van de IASB op het gebruik van buitengewone posten geleid te hebben tot het gebruik van een groot aantal verschillende en onvergelijkbare resultaatbegrippen die trachten inzicht te geven in het genormaliseerde resultaat.

Ook bij de presentatie van genormaliseerde resultaten zijn verschillen tussen de onderzochte landen zichtbaar. In 2005 rapporteerde slechts 12\% van de Duitse ondernemingen de alternatieve genormaliseerde winstbegrippen die voor het onderzoek geselecteerd zijn. Bij de Nederlandse ondernemingen ligt dit op 27\%, terwijl in Frankrijk en het Verenigd Koninkrijk respectievelijk $45 \%$ en $47 \%$ van de onderzochte ondernemingen een alternatieve maatstaf voor genormaliseerd resultaat opneemt. Over het geheel genomen is het gebruik van deze criteria in 2005 vergelijkbaar met 2004 (33\% versus 32\%).

Tabel 7: Percentage van ondernemingen dat alternatieve genormaliseerde winstbegrippen rapporteert in de jaarverslagen

\begin{tabular}{|l|r|r|}
\hline & $\mathbf{2 0 0 5}$ & $\mathbf{2 0 0 4}$ \\
\hline Verenigd Koninkrijk & $47 \%$ & $49 \%$ \\
\hline Frankrijk & $45 \%$ & $40 \%$ \\
\hline Nederland & $27 \%$ & $24 \%$ \\
\hline Duitsland & $12 \%$ & $9 \%$ \\
\hline Gewogen gemiddelde & $33 \%$ & $32 \%$ \\
\hline
\end{tabular}

Er zijn grote verschillen in de manier waarop genormaliseerde resultaten worden gepresenteerd, zowel tussen de landen als tussen de twee jaren die onderzocht zijn, zie tabel 8 . Het begrip 'bijzondere post' wordt vaak gehanteerd om niet-terugkerende 
elementen aan te duiden. Maar zowel in Frankrijk als in het Verenigd Koninkrijk is een afname (respectievelijk van $16 \%$ naar $6 \%$ en van $41 \%$ naar $30 \%$ ) te zien in het gebruik van begrippen als 'result' en 'profit before exceptional items'.

In het Verenigd Koninkrijk zijn veel ondernemingen de term 'underlying profit' gaan hanteren als maatstaf voor genormaliseerd resultaat (van 12\% naar 19\%). Dit compenseert de afname in het gebruik van resultaten 'before exceptional items'. In andere landen wordt het begrip underlying profit in veel mindere mate gehanteerd.

In Frankrijk wordt in toenemende mate gebruik gemaakt van 'current operating profit' of 'current operating income' als maatstaf voor genormaliseerd resultaat (stijging van 5\% naar 15\%). Dit prestatiecriterium wordt niet in de andere onderzochte landen gebruikt. Het gebruik van dit begrip in Frankrijk lijkt voort te komen uit de eerder genoemde aanbeveling van de Franse regelgever (CNC, 2004) om ook onder IFRS inzicht te blijven geven in de mate waarin het resultaat (naar verwachting) terugkeert. Ook resultaatbegrippen als 'before non-recurring items' komen in Frankrijk in hogere mate voor dan in de andere landen.

Hierbij kan men zich afvragen in hoeverre de verscheidenheid in het gebruik van prestatiecriteria die een genormaliseerd resultaat presenteren, van invloed is op het begrip dat de gebruiker van de jaarrekening heeft van de performance van de onderneming. Heeft 'underlying profit' bijvoorbeeld dezelfde betekenis als 'profit before exceptional items' of 'current operating income'? En betekent 'underlying profit' voor de ene onderneming wel hetzelfde als voor de andere? De presentatie van dergelijke winstbegrippen lijkt een gebied waarin duidelijkheid en consistentie voor alle betrokken partijen gewenst is.

\section{Besluit}

Zowel in paragraaf 2 als in paragraaf 3 blijkt uit de resultaten een grote diversiteit in de rapportage over resultaten en winstbegrippen. Zowel genormaliseerde winstbegrippen als winstbegrippen die bepaalde (afschrijvings)kosten buiten beschouwing laten, komen veel voor. Zowel in de mate van gebruik, als de wijze waarop begrippen worden aangeduid en gepresenteerd, bestaan grote verschillen tussen de onderzochte landen.

In het jaar van eerste toepassing van IFRS hebben veel ondernemingen de conversie gemaakt met beperkt vergelijkingsmateriaal van andere ondernemingen en zonder ervaringen en afstemming met investeerders, regelgevende instanties en andere partijen. De vele conferenties en sectorspecifieke IFRS-bijeenkomsten hebben zich primair gericht op de grondslagen voor waardering en resultaatbepaling, en minder op de presentatievereisten en mogelijkheden. Het is daarom niet verwonderlijk dat veel ondernemingen hun rapportage zo veel mogelijk hebben gebaseerd op wat ze gewend waren en op wat geaccepteerd werd door de lokale markt. Om die redenen valt het de ondernemingen in de EU eigenlijk niet te verwijten dat ze in 2005 niet altijd goed vergelijkbaar waren met hun branchegenoten, ondanks het feit dat ze allemaal hun jaarrekening hadden opgesteld op basis van IFRS.

De grote diversiteit roept echter de vraag op of IFRS overal in de EU consistent is toegepast en of de doelstelling van het verhogen van de vergelijkbaarheid van verslaggeving binnen de EU is bereikt. Zelfs bij toepassing van gelijke grondslagen kan door de grote diversiteit in presentatie bij beleggers en analisten gemakkelijk een perceptie zijn ontstaan dat er nog steeds grote verschillen bestaan tussen de verschillende IFRS-jaarrekeningen.

Tabel 8: Percentage ondernemingen per soort alternatief genormaliseerd winstbegrip

\begin{tabular}{|l|r|r|r|r|r|r|r|r|}
\hline & \multicolumn{2}{|c|}{ Before exceptional items } & Before non-recurring items & \multicolumn{2}{|c|}{ Underlying profit } & \multicolumn{2}{c|}{ Current operating income } \\
\hline & $\mathbf{2 0 0 5}$ & $\mathbf{2 0 0 4}$ & $\mathbf{2 0 0 5}$ & $\mathbf{2 0 0 4}$ & $\mathbf{2 0 0 5}$ & $\mathbf{2 0 0 4}$ & $\mathbf{2 0 0 5}$ & $\mathbf{2 0 0 4}$ \\
\hline Duitsland & $1 \%$ & $\mathbf{1} \%$ & $4 \%$ & $2 \%$ & $1 \%$ & $1 \%$ & $0 \%$ & $0 \%$ \\
\hline Frankrijk & $6 \%$ & $16 \%$ & $26 \%$ & $23 \%$ & $4 \%$ & $3 \%$ & $15 \%$ & $5 \%$ \\
\hline Nederland & $10 \%$ & $12 \%$ & $12 \%$ & $8 \%$ & $4 \%$ & $2 \%$ & $0 \%$ & $0 \%$ \\
\hline Verenigd Koninkrijk & $30 \%$ & $41 \%$ & $5 \%$ & $3 \%$ & $19 \%$ & $12 \%$ & $0 \%$ & $0 \%$ \\
\hline Gewogen gemiddelde & $\mathbf{1 6} \%$ & $\mathbf{2 2 \%}$ & $\mathbf{8 \%}$ & $\mathbf{5 \%}$ & $\mathbf{1 0 \%}$ & $\mathbf{6 \%}$ & $\mathbf{2 \%}$ & $\mathbf{1 \%}$ \\
\hline
\end{tabular}


Zou extra regelgeving de oplossing zijn? Binnen de op principes gebaseerde IFRS-regelgeving niet per se. Op bepaalde gebieden kan duidelijkheid en consistentie in IFRS voor iedereen wenselijk zijn, zoals de definitie van operationeel resultaat en de definitie en presentatie van bijzondere posten. Het IASB/FASB-project met betrekking tot de presentatie van de jaarrekening is echter nog onderhanden en het is niet de verwachting dat er op korte termijn nieuwe of gewijzigde standaarden komen die een oplossing bieden voor dit probleem. Maar ook al is duidelijk wat de beste oplossing zou zijn, dan nog is het niet waarschijnlijk dat via gedetailleerde regelgeving een oplossing tot stand kan komen die recht doet aan de verschillende informatiebehoeften van alle gebruikers en die is toegesneden op alle bedrijfstakken en individuele ondernemingen. Van groter belang op de korte en middenlange termijn lijkt het dat een constructieve dialoog tot stand komt tussen alle betrokken partijen over het gebruik van winstbegrippen, waarbij partijen elkaar aanspreken op de inachtneming van basisbeginselen als relevantie, consistentie en transparantie. In dat kader is het aan te bevelen dat ondernemingen in ieder geval de CESR-adviezen opvolgen.

Wat in ieder geval niet tot een grotere mate van consistentie lijkt te leiden zijn de uitingen van lokale regelgevers. Deze zorgen eerder voor een grotere diversiteit dan dat ze helpen bij de invoering van één internationaal verslaggevingsstelsel. Dit is een belangrijke boodschap voor nationale regelgevers. Partijen zijn niet gebaat bij het ontstaan van lokale versies van IFRS, dit zou in strijd zijn met de initiële doelstelling van de invoering van IFRS binnen de EU.

Dit artikel geeft de eerste resultaten weer van mijn onderzoek naar rapportage van winstbegrippen binnen de EU. Belangrijke vragen die ik in het vervolg van mijn onderzoek wil beantwoorden zijn allereerst wat motieven zijn voor ondernemingen om bepaalde winstbegrippen wel of niet te hanteren en daarnaast op welke wijze beleggers worden beïnvloed bij het nemen van investeringsbeslissingen door deze presentatiekeuzes van de ondernemingen. Pas als dit duidelijk is, kan worden bepaald welke maatregelen wenselijk zijn.

\section{Literatuur}

Accounting Standards Board (1992), FRS 3 Reporting Financial Performance. Backhuijs, J.B. en G.M.H. Mertens (2000), De presentatie winst en verliesrekening, in: Het jaar 1999 verslagen, Onderzoek jaarverslaggeving Nederlandse ondernemingen (red. J. Dijksma, J.A.G.M. Koevoets en R. G.A. Vergoossen), Kluwer, Deventer, pp. 110-133.

Brouwer, A.J. (2007), De winst is goed, maar hoe is de performance?, ControllersMagazine, jg. 21, nr. 3, maart, pp. 35-38.

Committee of European Securities Regulators (2005a), CESR Recommendation on Alternative Performance Measures; zie: www.cesr-eu.org.

Committee of European Securities Regulators (2005b), Press release - CESR consults on recommendations on the use of alternative performance measures to ensure best practice by companies in the information prepared for investors.

Conseil National de la Comptabilité (2004), Recommandation n²004-r.02 du 27 Octobre 2004 - Relative au format du compte de résultat, tableau des flux de trésorerie et tableau de variation des capitaux propres, des entreprises sous référentiel comptable international (hors entreprises de banque et d'assurance).

Dekker, P. (2005), Performance reporting onder IFRS, Maandblad voor Accountancy en Bedrijfseconomie, jg. 79, nr. 12, december, pp. 612-618.

European Financial Reporting Advisory Group (EFRAG) (2006), Pro-active Accounting Activities in Europe - Discussion Paper 2: The performance reporting debate - What (if anything ) is wrong with the good old income statement, November; zie: www.efrag.org.

Europees parlement en de raad van de Europese Unie (2002), Verordening (EG) $n r$. 1606/2002 van het Europees Parlement en de Raad van 19 juli 2002 betreffende de toepassing van internationale standaarden voor jaarrekeningen; zie: http://eur-lex.europa.eu/.

Financial Accounting Standards Board (FASB) (2002), Summary of User Interviews - Reporting Financial Performance by Business Enterprises; zie: www.fasb.org/project/interviews.pdf.

Financial Reporting Review Panel (FRRP) (2006), Preliminary report IFRS implementation; zie: www.frrp.co.uk.

Financieele Dagblad, Het (FD) (2004a), 'NIVRA eist herstel oud winstbegrip - Ebit(d)a taboe voor accountants', 14 januari, p. 1.

Financieele Dagblad, Het (FD) (2004b), 'Ebitda is voor ons buiten de orde NIVRA: Jaarverslagen wemelen van onvolkomenheden en foute begrippen', 14 januari, p. 11.

G4+1 (1999), Reporting Financial Performance: proposals for change Recommendations of the $\mathrm{G} 4+1$, juni.

Hooghiemstra, R.B.H., en L.G. van der Tas (2003), Rapportering over financial performance, in: Het jaar 2002 verslagen, Onderzoek jaarverslaggeving Nederlandse ondernemingen (red. J.B. Backhuijs, R.G. Bosman en C.D. Knoops), Kluwer, Deventer, pp. 73-100.

Hooghiemstra, R.B.H. en L.G. van der Tas (2004), Informatieverschaffing over prestatie-indicatoren, in: Het jaar 2003 verslagen, Onderzoek jaarverslaggeving Nederlandse ondernemingen (red. J.B. Backhuijs, R.G. Bosman en C. Camfferman), Kluwer, Deventer, pp. 91-118.

International Accounting Standards Board (2006), International Financial Reporting Standards (IFRSS $($ ) including International Accounting Standards (IAS ${ }^{\mathrm{TM}}$ ) and Interpretations as at 1 January 2006, IASB: London. International Accounting Standards Board (2005), Discussion Paper 
Management Commentary - A paper prepared for the IASB by staff of its partner standard-setters and others, oktober; zie: www.iasb.org.

IOSCO Technical Committee (2002), Cautionary Statement Regarding NonGAAP Results Measures, mei; zie: http://www.iosco.org/news/pdf/ IOSCONEWS4.pdf.

Jong, R.G.T. de, en E.M. Roelofsen (2005), IFRS en investor relations, ControllersMagazine, juni/juli, pp. 38-42.

Kamp, B. (2002), Kwaliteit van de winst, Maandblad voor Accountancy en Bedrijfseconomie, jg. 76, nr. 7/8, juli/augustus, pp. 328-336.

Marseille, E.A. en R.G.A Vergoossen (2005), Het gebruik van alternatieve financiële prestatie-indicatoren in persberichten, Maandblad voor Accountancy en Bedrijfseconomie, jg. 79, nr. 5, mei, pp. 196-204.

Raad voor de Jaarverslaggeving, Richtlijnen voor de jaarverslaggeving jaareditie 2005, Kluwer, Deventer.

Securities and Exchange Commission (SEC) (2001), Division of Corporation Finance: Frequently Requested Accounting and Financial Reporting Interpretations and Guidance, 31 maart 2001; zie. www.sec.gov.

Securities and Exchange Commission (SEC) (2002), SEC New Releases: SEC Brings First Pro Forma Financial Reporting Case; Trump Hotels Charged with Issuing Misleading Earnings Release, 14 januari; zie: www.sec.gov.

Securities and Exchange Commission (SEC) (2003), Conditions for Use of Non-GAAP Financial Measures, januari; zie: www.sec.gov.

Vander Bauwhede, H. (2003), Resultaatsturing en kapitaalmarkten - een overzicht van de academische literatuur, Maandblad voor Accountancy en Bedrijfseconomie, jg. 77, nr 5, mei, pp. 196-204.

Vlotman, F.W. (2005a), Ebitda en/of kasstroom, ControllersMagazine, jg. 19, nr. 9, november, pp. 24-27.

Vlotman, F.W. (2005b), Ebitda en/of winst, ControllersMagazine, jg. 19, nr. 10, december, pp. 42-45.

\section{Noten}

1 Waar in dit artikel wordt gesproken over jaarverslagen, wordt het gehele openbaar gemaakte document bedoeld, bestaande uit jaarverslag, jaarrekening en overige gegevens. Dit wordt ook wel aangeduid met de term jaarrapport.

2 Selectie heeft plaatsgevonden uit een overzicht van beursfondsen uit desbetreffende landen door middel van het genereren van 'random getallen'.

3 Integraal onderzoek onder de Nederlandse beursfondsen leert dat in 2005 door vijf ondernemingen EBITDA wordt gebruikt in de winst-enverliesrekening. 